\title{
Primary Branchiogenic Carcinoma
}

\author{
Primární branchiogenní karcinom
}

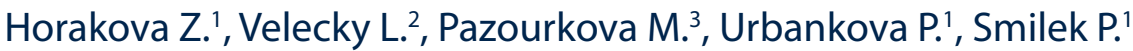 \\ 'Clinic of otorhinolaryngology head and neck surgery, Faculty of Medicine, Masaryk university, St. Anne's University Hospital, Brno, Czech Republic \\ 2 Department of pathology, Faculty of Medicine, Masaryk university, St. Anne's University Hospital, Brno, Czech Republic \\ ${ }^{3}$ Clinic of Medical Imaging, Faculty of Medicine, Masaryk university, St. Anne's University Hospital, Brno, Czech Republic
}

\begin{abstract}
Summary
Background: Primary branchiogenic carcinoma (BC) is an exceptional diagnostic entity. In most cases, suspicion of $\mathrm{BC}$ is confirmed to be a cystic lymph node metastasis of an occult primary tumor. Martin and Khafif therefore established diagnostic criteria, emphasizing above all the importance of a histologically assessed transformation of cystic lining epithelium into an invasive squamous cell carcinoma in one pathological lesion after the exclusion of a primary tumor. Case report: We present a case report of an 80-year-old patient who presented for a follow-up for an 8-year history of a benign lateral cervical cyst, which was not surgically treated due to the patient's high risk of complications from general anesthesia. In spite of the risk, the surgery was performed after a sudden clinical progression, and surprisingly, post-operative histology revealed BC. Conslusion: BC is a very rare entity, strictly defined by Martin's and Khafif's criteria. Recently, BCs have been presented in the literature only as unique case reports responding as in our patient to the above mentioned criteria, with particular emphasis on the histological aspect, imaging the cystic lining epithelium transforming into an invasive squamous cell carcinoma in one pathological lesion and a long history without evidence of primary tumor.
\end{abstract}

\section{Key words}

branchiogenic carcinoma - lateral branchial neck cyst - occult carcinoma - metastasis of unknown primary origin

Souhrn

Východiska: Primární branchiogenní karcinom (branchiogenic carcinoma-BC) v laterální krční cystě je výjimečná klinická jednotka. V naprosté většině prípadů se jedná o cystickou metastázu okultního primárního nádoru. Martin a Khafif stanovili diagnostická kritéria zdůrazňující především histologicky potvrzenou transformaci normální epiteliální výstelky cysty s přechodnou zónou transformace po jednoznačný invazivní karcinom a důsledné vyloučení primárního tumoru. Pozorování: Prezentován je prípad pacienta (80 let) s 8letou anamnézou zduření na krku - suspektní laterální krční cystou, pro kterou byl sledován. Chirurgické řešení nebylo indikováno pro významné interkurence. Přistoupeno bylo k exstirpaci až př̀i náhlé progresi infiltrátu. Histologie překvapivě odhalila $B C$, jednoznačně splňující kritéria. Závěr: Představujeme ojedinělý případ onemocnění, jehož existence je jednoznačně definována kritérii dle Martina a Khafifa. Nedávno byl v literatuře prezentován ojedinělý prípad splňující zmíněná kritéria, odpovídající i našemu pacientovi, s důrazem především na histologii dokumentující transformaci epitelu s přechodnou zónou až po invazivní spinocelulární karcinom v jedné patologické jednotce s dlouhodobým sledováním bez diagnostiky primárního nádoru.

\section{Klíčová slova}

branchiogenní karcinom - laterální krční cysta - okultní nádor - metastáza neznámého primárního nádoru
The authors declare they have no potential conflicts of interest concerning drugs, products, or services used in the study.

Autoři deklarují, že $v$ souvislosti s předmětem studie nemaji žádné komerční zájmy.

The Editorial Board declares that the manuscript met the ICMJE recommendation for biomedical papers.

Redakční rada potvrzuje, že rukopis práce splnil ICMJE kritéria pro publikace zasílané do biomedicínských časopisů.

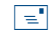

MUDr. Zuzana Horakova

Department of otorhinolaryngology head and neck surgery Faculty of Medicine of Masaryk university

St. Anne's University Hospital

Pekařská 664/53

65691 Brno

e-mail: zuhorakova@seznam.cz

Submitted/Obdrženo: 22. 2. 2018

Accepted/Přijato: 24. 4. 2018

doi: 10.14735/amko2018296 


\section{Introduction}

Primary branchiogenic carcinoma (BC) is a malignant tumor arising in branchial cervical cysts. It was first described by Volmann in 1882, and criteria were defined by Martin in 1950, which were then modified by Khafif in 1989 [1,2]. Branchial cyst presents as a smooth, soft ovoid cystic structure of the lateral neck originating in the remnant of an incompletely closed branchial cleft at the anterior margin of the sternocleidomastoid muscle. The lining of the cyst consists of a layered squamous cell epithelium from which its malignancy (squamous cell carcinoma SCC) develops. The BC diagnosis itself is accepted only when the strict criteria are met.
However, many authors still view the $B C$ only as a cystic metastasis of an undiagnosed occult primary tumor.

\section{Case Report}

An 80-year-old patient had been monitored in an ear, nose and throat (ENT) outpatient department for several years. Eight years ago, he was first exa-
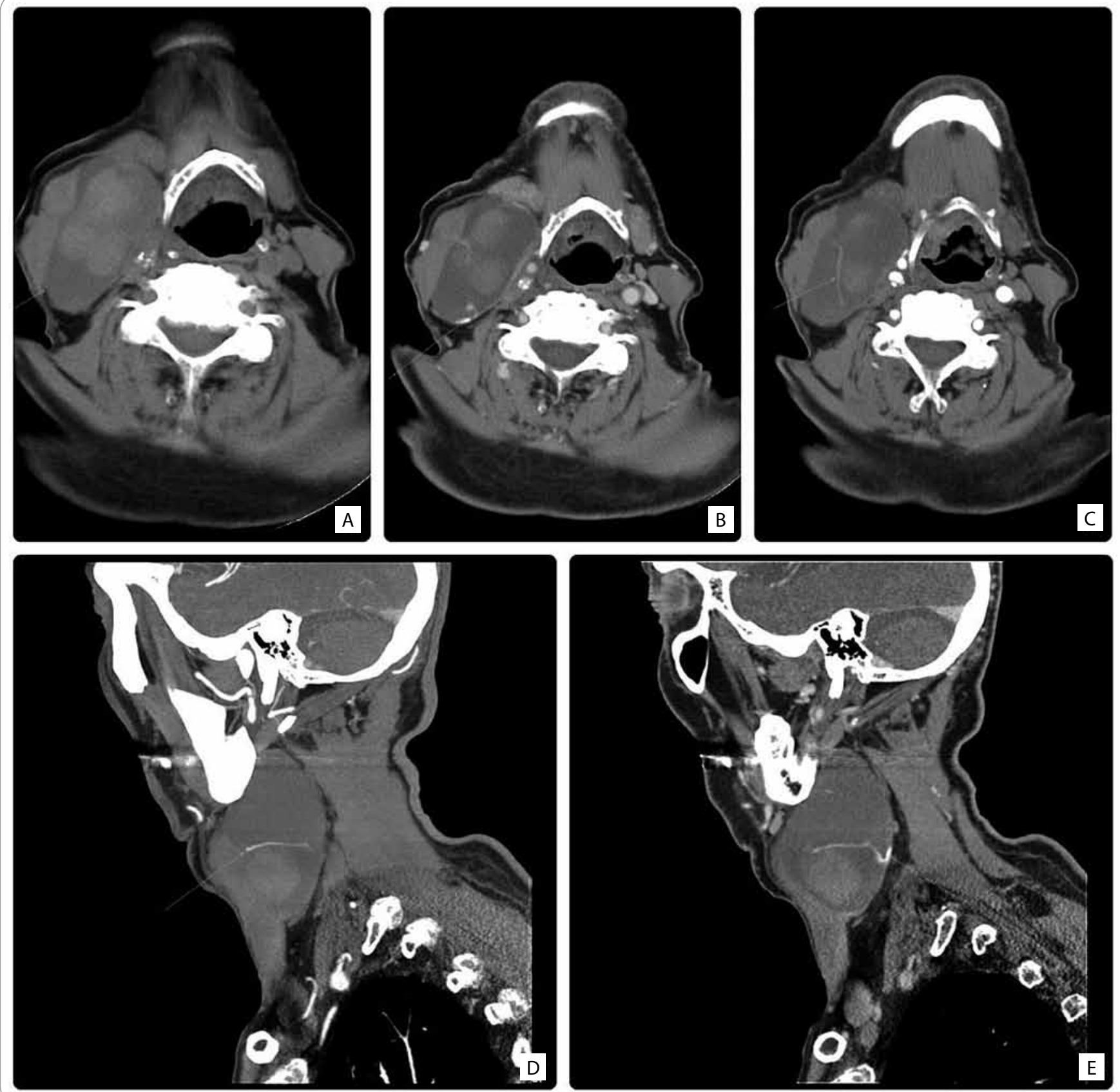

Fig. 1. A) A native CT image in the transversal plane - a cyst located among musculus sternocleidomastoideus, submandibular gland and vascular bundle with a inhomogeneous dense content and with a wall slightly irregular in width, $5.5 \times 3.3 \times 8.5 \mathrm{~cm}$ in size. B) Enhacement of the dorsal cyst wall after contrast medium application. C) The vessel in the early arterial phase. D) Sagittal reconstruction in the early arterial phase. E) Sagittal reconstruction in the late arterial phase. 
mined for a $6 \times 6 \mathrm{~cm}$, painless but slowly progressing lateral neck swelling of several months duration; otherwise he was symptom-free. A lateral cervical cyst was suspected (soft, elastic, fixed, painless, and located at the level of the middle third of the sternocleidomastoid muscle). The diagnosis was supported by ultrasound and CT scans - a thinwalled ovoid cystic formation with fluid content was displayed, without evidence of increased vascularization or pathological changes in the surrounding soft tissues, without neck lymphadenopathy; there was no other pathology under the regular (including endoscopic) ENT examination. As the patient was polymorbid, already suffering especially from cardiovascular diseases, the most conservative procedure was suggested. An aspiration biopsy was performed to reduce the volume and to exclude malignancy. The patient was regularly monitored. Regular aspiration of about $40-50 \mathrm{ml}$ of a serous fluid was performed approximately 2-4 times a year. Cytology never indicated suspicious malignancy. After 8 years, however, there was a clinical reversal; the swelling progressed significantly faster, and a sudden bleeding complication emerged after the puncture. The CT showed an ovoid structure, $65 \times 34 \times 87 \mathrm{~mm}$, but it was heterogenic, with a highly vascular wall of irregular width, pushing the neck vessel, deforming the hypopharynx (Fig. 1). Surgery was suggested despite the risk of general anesthesia.

A large cystic structure, located between the jugular vein and the sternocleidomastoid muscle, with inflammation in the surrounding tissues, was removed. The histology of the structure was surprisingly determined to be $B C$, fulfilling the criterion of the presence of a squamous cyst in the lining of the epithelium, the transition zone, and an invasive SCC comprised in the vestige.

Histology macroscopically identified a cystic structure $70 \times 35 \times 30 \mathrm{~mm}$ in size, the inner surface with cauliflower formations and blood coagulants and a smooth outer surface. Microscopically, the cyst consisted of a fibrohyalinic wall, lined with a squamous epithelium with areas of heavy metaplasia transforming to in situ carcinoma and finally to invasive G2/G3 differentiated SCC with focal keratinization (p53+, CK5+) (Fig. 2). Due to a complete removal, assuming nonaggressive biological behavior and taking into account the age of the patient no other general anesthesia associated with tonsillectomy and panendoscopy with guided biopsies were performed. For the same reason, adjuvant irradiation was not recommended. The patient has now been tumor-free for more than one year after finishing the treatment; he is under the follow-up care of a general practitioner.

\section{Discussion}

Martin first proposed criteria for the diagnosis of BC (Tab. 1) [1] and Khafif later modified these criteria (Tab. 2) [2]. As he disagreed with the third criterion (e.g. an independent duplex tumor can be detected over 5 years or, on the contrary, an administered adjuvant radiotherapy could eliminate an occult primary tumor), he replaced it with different two criteria - the absence of a primary tumor in a different location and a clear histological identification of a cystic structure where the normal squamous cell epithelium of the lining with transition zone of dysplasia, carcinoma in situ and an invasive SCC. These criteria are widely accepted. Both authors emphasize the histological aspect of BC.

$B C s$ have been published in recent years as unique case reports that meet Martin's and Khafif's above-mentioned criteria. Zimmerman documented the in situ carcinoma stage without clear invasion, which confirms the abovementioned etiopathogenetic theory [3]. The histological assessment was the strongest argument supporting the branchiogenic etiology in our case as well. Our patient met all of the criteria of localization, histological type of an invasive SCC, absence of primary malignancy and, above all, a characteristic, histologically well-documented process of transition.

Diagnosis of BC is based on clinical, cytological and radiodiagnostic imaging. Ultrasound, CT and MRI reveal a characteristic image - a thin-walled cystic lesion with a back wall enhancement. However, an atypia may always arise (pseudosolid, anechogenous, heterogeneous, with debris and pseudocysts or an indistinguishable wall), which is associated with a change in cyst content in intra-capsule bleeding or solidification, thickening of the wall caused by inflammation, or an increase in vascularization which may indicate a malignant transformation. We consider ultrasound to be an ideal follow-up method, as it is non-burdensome and applicable in regular intervals and allows for guided aspiration biopsy for cytological assessment [4].

CT corresponded with the diagnosis of a benign cyst in our patient for a long period until a rapidly progressing symptomatology recently arose. This, however, was more suspected to be inflammation induced by a repeated Fine needle aspiration biopsy (FNAB) (cytology was always benign.)

For BC diagnostics, the issue is first and foremost to exclude an occult primary head and neck tumor metastasis; in the past, this diagnosis was probably overestimated, whereas nowadays some authors completely deny the existence of $B C$ as a pathologic unit itself.

On the other hand, the histology illustrating a transition of the epithelium to the carcinoma is the strongest argument supporting the existence of this clinical unit, which has never been explained in another way [5-7].

Cancer of unknown primary origin (CUP) presenting with cervical metastasis accounts for approximately $5 \%$ of all head and neck malignancies, over $90 \%$ of which, as it was later assessed, originate from the lymphatic tissue (tonsil, nasopharynx, root of the tongue).

Though recent theories suggest that a small primary tumor may be eliminated by the patient's immune system, examination, including panendoscopy, biopsy from Waldeyer's ring and bilateral tonsillectomy are vastly recommended. Positron-emission tomography imaging is indicated for excluding a primary tumor during the diagnostic procedure and subsequent follow-up, when a metastasis of unknown primary should be confirmed [8-10]. 

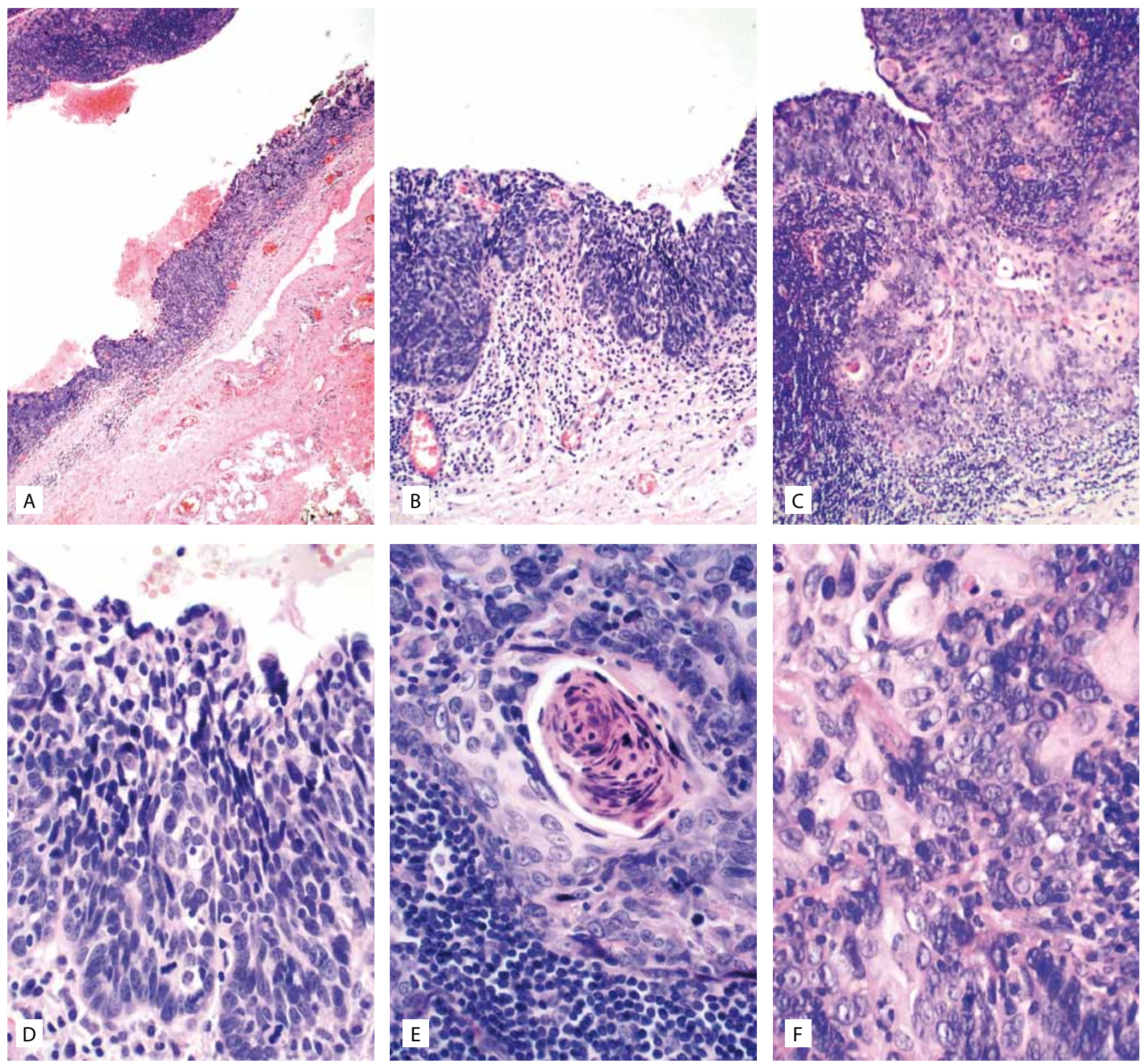

Fig. 2. A) Branchial cleft cyst with epithelial dysplasia (40x). B) Branchial cleft cyst with high-grade epithelial dysplasia/squamous cell carcinoma in situ (100x). C) Invasive squamous cell carcinoma arising in the wall of branchial cleft cyst (100x). D) Epithelium with high-grade dysplasia/squamous cell carcinoma in situ (400x). E) Epithelium with high-grade dysplasia/squamous cell carcinoma in situ (400x). F) Nest of invasive squamous cell carcinoma, G3 (400x).

In recent years, oropharyngeal location is regarded as particularly susceptive considering the dramatic increase in incidence of human papillomavirus (HPV)-associated oropharyngeal carcinomas (OPC), known for its early cystic metastases of small primary tumors. OPC is finally diagnosed in up to $70 \%$ of cases. From the HPV point of view, an interesting case of HPV-associated BC was reported by Maeda [11-15].
In our patient, the immunohistochemistry was negative for $\mathrm{p} 16$, which also supports the non-HPV etiology.

In our patient, histology was a great surprise considering the long-lasting history with a benign FNAB cytology. We do not believe the malignancy could persist for such a long time.

Another theory might arise - the malign transformation could be brought on by repeating FNAB; however, this was not supported by any report in the reviewed literature.

Therefore, endoscopy followed, but a tonsillectomy was not performed. The patient had a very high risk of general anesthesia and there was no clinical suspicion of tumor. The 8-year history of cystic lesion in the lateral neck, free of progression even without any treatment, is a very strong argument against the theory of occult tumor metastasis. 
Tab. 1. Criteria for the diagnosis of branchiogennic carcinoma by Martin [1].

1 The cevical tumor must have occurred somewhere along the line extending from a point just anteriot to the tragus, downward along the anterior border of the sternocleidomastoid muscle to the clavicle.

2 The histologic appearance of the growth must be consistent with an origin from tissue known to be present in the branchial vestiga.

3 The patient must have survived and have been followed up for at least 5 years withou the primary tumor.

$4 \quad$ The histologic demonstration of cancer developing in the wall of an epithelial cyst situated in the lateral aspect of the neck (a normal branchiogenic cyst).

Tab. 2. Criteria modified by Khafif [2].

1 The location of the tumor in the anatomic region of the branchial cleft cyst or sinus as defined by Martin.

2 Histologic appearance of the tumor consistent with its origin from vranchial vestiges, ilel squamous cell carcinoma.

3 Presence of carcinoma within the linig of an identifiable epithelial cyst.

4 Identification of transition from the normal squamous epithelium of the cyst to carcinoma.

5 Absence of any identifiable primary malignant tumor after exhaustive evaluation of the patient.

Complete surgical excision and adjuvant radiotherapy is considered to be an adequate therapy; even though data are rare in a rare diagnosis, a good prognosis is assumed. In our patient, a complete excision of a large cyst was performed. On account of the patient's performance status, recommended panendoscopy and tonsillectomy were not performed. However, even though the suggested adjuvant radiotherapy could not be performed, he is, after a year of follow-up, recurrence-free under regular clinical examination.

\section{Conclusion}

$B C$ is a very rare entity, strictly defined by Martin's and Khafif's criteria. The existence of BC itself is denied by some authors and pathologists and is considered to be the cystic metastasis of an unknown primary tumor.

In recent years, $\mathrm{BCs}$ have been presented in the literature only as unique case reports responding to the above mentioned criteria, with particular emphasis on the histological aspect, imaging the cystic lining epithelium transforming into an invasive SCC in one pathological lesion.

\section{References}

1. Martin H, Morfit HM, Ehrlich H. The case for branchiogenic cancer (malignant branchioma). Ann Surg 1950; 132(5): 867-887

2. Khafif RA, Prichep R, Minkowitz S. Primary branchiogenic carcinoma. Head Neck 1989; 11(2): 153-163.

3. Zimmermann CE, von Domarus H, Moubayed P. Carcinoma in situ in a lateral cervical cyst. Head Neck 2002; 24(10): 965-969 doi: 10.1002/hed.10118.

4. Hu S, Hu Ch, Yang L et al. Atypical imaging observations of branchial cleft cysts. Oncol Lett 2014; 7(1): 219-222. doi: 10.3892/ol.2013.1656.

5. Lin YC, Fang SY, Huang RH et al. Branchiogenic squamous cell carcinoma: a case report. Int J Oral Myillofac Surg 2004; 33(2): 209-212.

6. Girvigian MR, Rechdouni AK, Zeger D et al. Squamous cell carcinoma arising in a second branchial cleft cyst. Am J Clin Oncol 2004; 27(1): 96-100

7. Nakano A, Misima K, Katase N. A case of squamous cell carcinoma arising from branchial cleft cyst. Oral Maxillofac Surg 2015; 73(4): 781-785. doi: 10.1016/j. joms.2014.10.036.

8. Zdražil B, Profant M, Povinec P. Prínos PET CT vyšetrenia do diagnostiky neznámého primárného tumoru s metastázováním do krčných lymfatických uzlín naše skúsenosti. Otorinolaryng Foniat 2012; 61(1): 53-56.

9. National Comprehensive Cancer Network. [online]. Available from: https://www.nccn.org/professionals/physician_gls/pdf/head-and-neck.pdf.

10. Mackenzie K, Watson M, Jankowska P et al. Investigation and management of the unknown primary with metastatic neck disease: United Kingdom National Multidisciplinary Guidelines. J Laryngol Otol 2016; 130 (Suppl 2): S170-S175. doi: 10.1017/S0022215116000 591.

11. Maeda H, Deng Z, Ikegami T et al. Branchiogenic carcinoma with high-risk-type human papillomavirus infection: a case report. Oncol Lett 2016; 12 (3): 2087-2091. doi: 10.3892/ol.2016.4907.

12. Chauhan A, Tiwari S, Pathak N. Primary branchiogenic carcinoma: report of a case and a review of the literature. J Can Res Ther 2013; 9(1): 135-137. doi: 10.4103/09731482.110380

13. Schmalbach CE, Miller FR. Occult primary head and neck carcinoma. Curr Oncol Rep 2007; 9(2): 139-146

14. Goldenberg D, Sciubba J, Koch WM. Cystic metastasis from head and neck squamous cell cancer: a distinct disease variant. Head Neck 2006; 28(7): 633-638. doi: 10.1002/hed.20381.

15. Yasui T, Morii E, Yamamoto $Y$ et al. Human papillomavirus and cystic node metastasis in oropharyngeal cancer and cancer of unknown primary origin. PLoS One 2014; 9(4): e95364. doi: 10.1371/journal.pone.0095 364. 